\title{
KONSTRUKSI KEPEMIMPINAN TOKOH BANGSA DALAM FILM KETIKA BUNG DI ENDE
}

\author{
Septizar Triastika \\ Program Studi Pascasarjana Ilmu Komunikasi, Fakultas Ilmu Sosial dan Ilmu Politik, Universitas Indonesia \\ Jl. Salemba Raya No. 4 Jakarta 10340 \\ No. Telp./HP: 081285502827 \\ E-mail: septizar.triastika@gmail.com
}

Naskah diterima tanggal 17 Februari 2016, direvisi tanggal 9 Mei 2016, disetujui tanggal 21 Juni 2016

\section{NATIONAL FIGURE LEADERSHIP CONSTRUCTION IN THE MOVIE "KETIKA BUNG DI ENDE"}

\begin{abstract}
This research discusses Soekarno's leadership construction as a national figure framed in the movie "Ketika Bung di Ende" as a film that raised the critical phase which rarely examined in the life of Soekarno. This study rests on the theory of Construction Reality Peter L. Berger and Thomas Luckman through movie as a mass media. Using the framing analysis of William A. Gamson and Andre Modgliani to see how the events are governed by the ideas and its problems, by using Metaphors, Catchphrases, Exemplar, Depiction and Visual Images as well as reasoning devices with the use of roots, appeals to principle, and consequences as Framing Devices; the director and the screenwriter then form their intended construction on Soekarno's leadership. The conclusions obtained from this study are as a medium of communication, the movie can be used to construct Soekarno as a free-spirited leader and anti imperialism; eager and devoted to unity, embracing all people, and religious ideologues. Soekarno is a leader with democratic and transformational constellation of traits that still adheres to the philosophy of Pancasila.
\end{abstract}

Keywords: construction, framing, leadership, a national figure, movie.

\begin{abstract}
Abstrak. Penelitian ini membahas mengenai konstruksi kepemimpinan Soekarno sebagai tokoh bangsa yang dibingkai dalam film Ketika Bung di Ende sebagai film yang mengangkat fase penting yang jarang diteliti dalam kehidupan Soekarno. Penelitian ini bersandar pada teori Konstruksi Sosial. Menggunakan analisis framing dari William A. Gamson dan Andre Modgliani untuk melihat bagaimana gagasan yang mengatur cara memaknai kejadian dan apa yang menjadi permasalahan, dengan menggunakan perangkat framing (Framing Devices) melalui Metaphors, Catchphrases, Exemplar, Depiction dan Visual Images serta perangkat penalaran (reasoning devices) dengan menggunakan roots, appeals to principle dan consequences sebagai Framing Devices. Strategi framing tersebut digunakan untuk membentuk konstruksi yang ingin dibentuk oleh sutradara dan penulis skenario. Simpulan yang didapatkan dari penelitian ini adalah sebagai salah satu media komunikasi, film memberikan konstruksi atas kepemimpinan Soekarno sebagai pemimpin yang berjiwa bebas dan anti imperialisme, bersemangat dan gandrung pada persatuan, merangkul semua kalangan, dan ideologi religius. Kepemimpinan Soekarno adalah constellation of traits yang demokratis, transformasional, dan menganut falsafah Pancasila.
\end{abstract}

Kata kunci: konstruksi, framing, kepemimpinan, tokoh bangsa, film. 


\section{PENDAHULUAN}

Penjajahan yang dialami Indonesia pada waktu itu melahirkan berbagai pergerakan politik maupun sosial, hingga pada tahun 1920-an gagasan Indonesia sebagai cita-cita yang hendak dicapai untuk mengusir Belanda dan memerdekakan tanah air menjadi dominan di kalangan aktivis politik.

Penjajahan yang berlangsung selama kurang lebih empat abad yang dialami Indonesia di masa lalu, dapat terjadi karena ketiadaan sosok pemimpin yang sanggup menyatukan Nusantara menjadi sebuah negara yang menjadi masalah utama saat itu. Sehingga, potensi-potensi yang dimiliki Indonesia menjadi ancaman bagi bangsa ini, bahkan hingga saat ini. Karena itulah, Indonesia membutuhkan sosok pemimpin yang bisa mengayomi dan mempersatukan semua perbedaan serta mengelola seluruh sumber daya yang dimiliki Indonesia.

Masalah kepemimpinan di Indonesia adalah sebuah topik yang menarik untuk dibicarakan. Terlebih kalau dilihat dari cikal bakal terbentuknya Bangsa Indonesia yang dipenuhi dengan perjuangan dan pengorbanan dari para founding fathers Indonesia. Dasar pemikiran dan falsafah Bangsa Indonesia yang digunakan hingga saat ini, sangat ditentukan oleh pemimpin-pemimpin yang berjuang untuk mendirikan bangsa Indonesia di masa lalu. Kepemimpinan utama sebuah bangsa, ada di tangan presiden. Sebagai presiden pertama Republik Indonesia, Soekarno mengawali kepemimpinannya melalui berbagai organisasi sebagai wadah perjuangan untuk memperjuangkan nasib Indonesia. Hal yang penting dari seorang pemimpin adalah kepemimpinan. Sehingga menjadi sangat penting untuk membahas lebih lanjut tentang kepemimpinan bangsa, khususnya tokoh Soekarno, untuk memahami lebih dalam kepemimpinan tokoh utama pendiri bangsa Indonesia sebagai salah satu referensi berharga dalam mengurai permasalahan yang dihadapi Bangsa Indonesia di masa kini maupun di masa yang akan datang.
Perjalanan Bangsa Indonesia untuk memerjuangkan kemerdekaannya baik pada masa penjajahan, maupun perjuangan setelah Proklamasi Kemerdekaan Indonesia tidak bisa dilepaskan dari sosok Soekarno dan Mohammad Hatta sebagai pemimpin bangsa Indonesia. Terlebih sosok Soekarno yang sejak remaja sudah berjuang untuk kemerdekaan Indonesia melalui berbagai organisasi yang menjadi wadah perlawanannya terhadap kolonialisme Belanda. Soekarno harus keluar masuk penjara berkali-kali karena perlawanannya tersebut. Peran Soekarno untuk Indonesia sangat besar, sebab Soekarno adalah pemimpin utama perlawanan terhadap penjajahan kolonialisme yang akhirnya berhasil dengan terciptanya Negara Kesatuan Republik Indonesia. Dengan begitu, Soekarno pantas diberi gelar salah satu founding fathers Indonesia.

Soekarno presiden pertama Republik Indonesia, lahir di Surabaya, Jawa Timur, 6 Juni 1901 dan meninggal di Jakarta, 21 Juni 1970. Ayahnya bernama Raden Soekemi Sosrodihardjo dan ibunya Ida Ayu Nyoman Rai. Ia bersekolah pertama kali di Tulung Agung hingga akhirnya ia pindah ke Mojokerto, mengikuti orangtuanya yang ditugaskan di kota tersebut. Di Mojokerto, ayahnya memasukkan Soekarno ke Eerste Inlandse School, sekolah tempat ia bekerja. Pada tahun 1915, Soekarno telah menyelesaikan pendidikannya di ELS dan berhasil melanjutkan ke HBS di Surabaya, Jawa Timur. Semasa di Surabaya, dia tinggal di rumah Haji Oemar Said Tjokroaminoto. Saat belajar di HBS itu, Soekarno telah menggembleng jiwa nasionalismenya. Selepas lulus HBS tahun 1920, pindah ke Bandung dan melanjut ke THS (Technische Hoogeschool atau Sekolah Teknik Tinggi yang sekarang menjadi ITB). Kemudian, dia merumuskan ajaran Marhaenisme dan mendirikan PNI (Partai Nasional Indonesia) pada 4 Juli 1927, dengan tujuan Indonesia Merdeka. Akibatnya, Belanda, memasukkannya ke penjara Sukamiskin, Bandung pada 29 Desember 1929. Delapan bulan kemudian baru disidangkan. 
Pembelaannya di muka persidangan, membuat Belanda makin marah. Sehingga pada Juli 1930, PNI pun dibubarkan. Setelah bebas pada tahun 1931, Soekarno bergabung dengan Partindo dan sekaligus memimpinnya. Akibatnya, dia kembali ditangkap Belanda dan dibuang ke Ende, Flores, tahun 1933. Empat tahun kemudian dipindahkan ke Bengkulu untuk menjalani politik pengasingan akibat aktivitas politik non koperasi melalui Partindo.

Menurut Dhakidae (2013b), kehidupan politik Soekarno dapat dibagi menjadi lima bagian, antara lain: Pertama, masa ketika Soekano mulai masuk ke dunia politik melalui manifesto Soekarno saat ia menulis "Islam, Marxisme dan Nasionalisme"; Kedua, saat masa pembuangan ke Ende dan Bengkulu; Ketiga, masa pendudukan dan penjajahan Jepang; Keempat, masa kemerdekaan sejak Soekarno-Hatta menjadi pemimpin Indonesia hingga Pemilihan Umum tahun 1955; Kelima, saat Soekarno mengumumkan pelaksanaan Demokrasi Terpimpin dan presiden seumur hidup hingga kejatuhannya pada 1965. Hampir semua masa dalam episode-episode sejarah tersebut sudah ditulis dan dibahas dengan fakta, kecuali tentang masa kedua, terutama tentang Ende. Ende dan pembuangan Soekarno ke sana tidak/belum menarik perhatian para peneliti. Sedikit sekali sarjana, peneliti, penulis yang berminat tentang itu.

Dalam sejarah Indonesia, Ende hanyalah tempat pembuangan, namun bagi Soekarno Ende berkontribusi karena political silence yang ada di Ende pada umumnya menghidupkan Soekarno the man. Hanya di Ende Soekarno tampil sebagai dirinya sendiri tanpa topeng-topeng aktivis, nasionalis, dan pemimpin besar revolusi. Ende menjadi sangat penting untuk Soekarno baik secara pribadi maupun Soekarno sebagai manusia publik bagi Indonesia. Di Ende, Soekarno bertransformasi dari manusia "singa podium" menjadi "manusia perenung" yang reflektif, religius, dan pemikir hingga salah satunya menghasilkan pemikiran tentang Pancasila sebagai falsafah dasar Indonesia. Sebagai seniman, di Ende Soekarno mengasah keahliannya sebagai sutradara 12 tonil (sandiwara) yang selalu dipentaskan dengan tema kemerdekaan dan pembebasan dari kolonialisme. Kontribusi Ende dalam kehidupan Soekarno adalah sebagai kawah candradimuka. Soekarno yang datang ke Ende adalah Soekarno, yang menurut Moh. Hatta, telah mati. Namun, pengalaman psikologis, intelektual, ideologis yang dialami Soekarno di Ende mengangkat "tempat pembuangan" menjadi "tempat pemulihan" untuk tercerahkan dan bergerak menjadi de Japansche Colaborateur untuk memerdekakan Indonesia kelak (Dhakidae, 2013a). Dari seluruh masa Soekarno muda, sejarawan dari Lembaga Ilmu Pengetahuan Indonesia, Asvi Warman Adam dalam Sutanto and Harapan (eds.) (2003), menilai periode 1926-1930 adalah puncak kreativitas pemikiran Soekarno akan nasionalisme dan sikap kerasnya menentang kolonialisme. Juga kegandrungannya pada persatuan. Karakter Soekarno sebagai pemersatu dan aktivis anti imperialis yang militan terlihat jelas di era ini.

Sebagai suatu negara, Indonesia digerakkan oleh tiga pilar utama yaitu legislatif, eksekutif, dan yudikatif yang bersama-sama mengawal jalannya pemerintahan. Peran media massa sebagai pilar keempat demokrasi, memiliki fungsi sebagai kontrol sosial (Luwarso et al., 2002). Dalam konteks ini media massa berperan sebagai representasi atas pengawasan masyarakat. Sehingga konstruksi yang dibangun oleh media massa mewakili konstruksi masyarakat. Media massa, apapun bentuknya, membawa dampak bagi masyarakat karena masyarakat mengolah hasil konstruksi realitas yang dilakukan media massa. Sehingga konstruksi media akan realitas sedikit banyak akan menentukan cara pandang masyarakat terhadap realitas. Menurut Eriyanto (2007), media massa bukanlah saluran yang bebas, ia juga subjek yang mengonstruksi realitas, lengkap dengan bias dan keberpihakannya. Media dipandang sebagai agen konstruksi sosial yang mendefinisikan realitas.

Mulyana (dalam Eriyanto 2007) menyatakan bahwa media massa Indonesia 
sangat kaya dengan wacana. Perubahan konstelasi kekuasaan antara berbagai komponen suatu bangsa, masyarakat, dan komunitas. Ketika Orde Baru berkuasa, filmfilm perjuangan yang dihadirkan sarat dengan simbol-simbol yang menyatakan betapa hebatnya Soeharto sebagai penguasa kala itu. Hal ini menunjukkan film dapat dipandang sebagai media yang turut menjadi pilar demokrasi suatu bangsa. Selanjutya, Mulyana menyatakan bahwa untuk melihat realitas di balik wacana media, dibutuhkan paradigma yang lebih kritis, framing adalah salah satunya. Analisis framing merupakan suatu seni atau kreativitas yang kesimpulannya boleh jadi berbeda meskipun kasusnya sama, sebab analis bebas menafsirkan lingkungannya dan konteks sosial budaya suatu wacana.

"Ketika Bung di Ende" adalah film yang digarap PT. Cahaya Kristal Media Utama bersama Kementerian Pendidikan dan Kebudayaan khusus untuk mengangkat kehidupan Soekarno selama diasingkan di Ende. Film ini disutradarai oleh Viva Westi yang sekaligus menjadi penulis skenario dan dibantu oleh Tb. Deddy Safiudin. Beberapa artis pun turut serta dalam film tersebut seperti Baim Wong yang berperan sebagai Soekarno, Paramitha Rusady sebagai Inggit Ganarsih, dan didukung oleh artis lain seperti Tio Pakusadewo dan Ninik L. Karim serta melibatkan penduduk lokal Ende.

Film "Ketika Bung di Ende" merupakan film sejarah yang berusaha mengonstruksi tokoh Soekarno dalam masa pengasingannya di Ende. Irawanto (1999) menyatakan, film merupakan salah satu media yang dapat merepresentasikan peristiwa yang terjadi di masa lalu kepada generasi di masa selanjutnya dan memberikan pemahaman atas peristiwa-peristiwa dan tokoh-tokoh sejarah. Film dapat menjadi sarana untuk mendokumentasikan sekaligus mengabadikan sejarah. Selain itu, selain sebagai sarana hiburan, film juga menjadi medium penyampaian pesan dan representasi kejadian yang ditampilkan dalam film. Dalam hal memproduksi wacana, hegemoni, dan nilainilai sosial, film termasuk sebagai salah satu produk media massa. Film memang memiliki karakter yang lebih mirip dengan media hiburan, namun film mempunyai kesempatan untuk lebih berkontribusi bagi masyarakat, karena pada prinsipnya film tidak dibatasi oleh pakem tertentu, layaknya jurnalisme cetak maupun penyiaran yang harus memertimbangkan prinsip kelayakan berita (Irawanto, 1999).

Marc Ferro dalam Sutanto and Harapan (eds.) (2003) menjelaskan gagasan tentang hubungan antara film dengan sejarah yang dapat dilihat dari berbagai poros. Pertama, film sebagai sumber sejarah, karena film dapat dijadikan sebagai dokumentasi resmi peristiwa-peristiwa penting dalam sejarah. Kedua, film juga berfungsi sebagai agen sejarah. Salah satu contohnya adalah film propaganda sebagai pembawa ideologi pihak yang berkuasa. Sejajar dengan fungsi film sebagai sumber sejarah, kalangan non perfilman dapat memanfaatkan film untuk melihat le non-dit des societes (apa yang tidak dikatakan oleh masyarakat). Apa yang tidak muncul dalam pidato atau percakapan resmi, tetapi terjadi di masyarakat juga dapat terekam dalam film. Sehingga akan memiliki wacana yang kaya tentang sejarah bangsa ini.

Menurut Berger dan Luckmann (dalam Samuel 1993), realitas dibangun secara sosial (bersifat objektif) dan berbeda dengan pengetahuan (bersifat subjektif). Media, dalam hal ini film mengonstruksi realitas tertentu pada masyarakat, dan masyarakat mengolah hasil konstruksi yang dilakukan media massa melalui proses internalisasi. Dengan begitu konstruksi media terhadap realitas akan memengaruhi konstruksi masyarakat terhadap realitas tersebut. Eriyanto (2007) menjelaskan bahwa media massa bukanlah saluran yang bebas, ia juga subjek yang mengonstruksi realitas dan mengandung bias dan keberpihakan. Media dipandang sebagai agen konstruksi sosial yang mendefinisikan realitas media, dalam hal ini memilih realitas mana yang diambil dan mana yang tidak diambil. Hamad (2004) menyampaikan bahwa dalam mengonstruksi realitas, para pihak pelaku konstruksi menggunakan bahasa (strategy signing), 
mengatur fakta (strategy framing), dan menyesuaikan waktu yang tepat untuk menyampaikan pesan (strategy priming).

Dari ketiga hal tersebut, framing dianggap sebagai yang terpenting karena framing menentukan realitas yang lebih menonjol, membesarkan cara bercerita sehingga audiens lebih mudah mengingat aspek - aspek tersebut dan memaknai peristiwa berdasarkan maksud pembuat film. Penggunaan bahasa dan waktu yang tepat untuk menyampaikan pesan (signing dan priming) pada dasarnya mendukung framing yang diinginkan oleh pembuat film. Dalam proses pengemasan pesan atau framing, media secara leluasa memilih kejadian dan dialog apa saja yang akan dimasukkan dalam adegan-adegan film. Berdasarkan tindakan ini, media akhirnya menentukan gambaran atau image yang terbentuk dalam benak audiens terhadap peristiwa sejarah dan tokoh tertentu.

Penelitian ini menggunakan model analisis framing dari W. A. Gamson dan Andre Modigliani. Peneliti menggunakan model analisis ini karena Gamson dan Modigliani dalam Eriyanto (2001) memandang frame sebagai cara bercerita (story line) atau gugusan ide-ide yang tersusun sedemikian rupa dan menghadirkan konstruksi makna dari peristiwa yang berkaitan dengan suatu wacana.

Sebagai film pertama tentang Soekarno yang diproduksi oleh Kementerian Pendidikan dan Kebudayaan, film Ketika Bung di Ende penting untuk diteliti lebih lanjut, karena diasumsikan membawa misi tertentu. Bagaimana tokoh Soekarno dikonstruksikan dalam film ini, termasuk peristiwa-peristiwa yang menyertainya dipengaruhi oleh proses internalisasi yang dilakukan oleh pembuat film. Proses tersebut memengaruhi dan dipengaruhi oleh konstruksi realitas tentang kepemimpinan Soekarno yang telah ada. Sehingga hasil dari film yang di dalamnya ada penokohan Soekarno diasumsikan akan memengaruhi cara pandang masyarakat (Sen, 1994). Telah banyak kajian mengenai analisis framing atas isi media, namun belum ada analisis framing dalam film sebagai media yang mengangkat kepemimpinan tokoh Soekarno sebagai salah satu pendiri utama bangsa Indonesia. Hal inilah yang menjadi alasan mengapa studi ini perlu dilakukan dengan berfokus pada film yang mengangkat tokoh Soekarno, yaitu bagaimana framing kepemimpinan dia dalam film.

Dari permasalahan di atas, bisa dirumuskan pertanyaan penelitian: Bagaimana konstruksi realitas kepemimpinan Soekarno melalui bingkai (framing) dalam film?

\section{LANDASAN KONSEP}

Kepemimpinan adalah proses, dalam hal ini individu memengaruhi sekelompok individu untuk mencapai tujuan bersama. Penetapan kepemimpinan sebagai proses berarti kepemimpinan itu tidak bersifat linier dan bukan peristiwa satu arah, tetapi merupakan peristiwa yang interaktif. Ada banyak pengelompokan yang dilakukan oleh para ahli terkait tipe-tipe kepemimpinan. Salah satunya adalah yang dikemukakan oleh Kartono (2006) dalam bukunya "Pemimpin dan Kepemimpinan". Tipe-tipe tersebut antara lain: Tipe Kepemimpinan Kharismatis, Tipe Kepemimpinan Paternalistis/Maternalistik, Tipe Kepemimpinan Militeristik, Tipe Kepemimpinan Otokratis (Outhoritative, Dominator), Tipe Kepemimpinan Laissez Faire, Tipe Kepemimpinan Populistis, Tipe Kepemimpinan Administratif/Eksekutif dan Tipe Kepemimpinan Demokratis (Kartono, 2006). Teori kepemimpinan yang lain juga dikemukakan Northouse (2013) yang mengklasifikasikan jenis-jenis kepemimpinan menjadi tiga, yaitu: Kepemimpinan Transformasional, Kepemimpinan yang melayani dan Kepemimpinan Autentik. Kepemimpinan transformasional adalah termasuk dalam paradigma kepemimpinan Baru yang lebih memberi perhatian pada elemen kepemimpinan yang karismatik dan peka. Kepemimpinan transformasional melalui proses yang mengubah orang-orang 
dan peduli dengan emosi, nilai, etika, standar, dan tujuan jangka panjang. Hal ini termasuk menilai motif pengikut, memuaskan kebutuhan mereka, dan memperlakukan mereka sebagai manusia secara utuh. Kepemimpinan transformasional mencakup bentuk pengaruh luar biasa yang menggerakkan pengikut untuk mencapai lebih dari apa yang biasanya diharapkan dari mereka. Ini adalah proses yang seringkali menyertai kepemimpinan yang bersifat karismatik dan visioner. Dalam cakupan komunikasi politik, Nimmo (1978) mengemukakan tiga teori kepemimpinan. Teori kepemimpinan pertama berpendapat bahwa pemimpin berbeda dari massa rakyat karena karakteristik dan sifat yang sangat dihargai. Semua pemimpin dalam semua proses peristiwa dan kebudayaan, memiliki karakteristik ini, sehingga disebut unitary trait. Ada dua variasi dalam tipe kepemimpinan ini, yang pertama adalah Great Man Theory dan tipe pemimpin yang memiliki sifat tertentu yang membuatnya berbeda. Teori kedua adalah teori konstelasi sifat (Constellation of Traits Theory). Dalam teori ini, pemimpin memiliki sifat-sifat yang sama dengan yang dimiliki oleh orang kebanyakan, namun tetap memadukan sifatsifat ini dalam ciri-ciri kepemimpinan yang membedakannya dari orang lain, misalnya tahan terhadap tekanan, tidak bergantung pada orang lain dalam memecahkan masalah, dan sebagainya. Para peneliti kepemimpinan selanjutnya mengemukakan satu teori baru yang disebut sebagai teori kepemimpinan situasionalis. Teori ini berpendapat bahwa waktu, tempat, dan keadaan yang menentukan siapa yang memimpin dan siapa yang menjadi pengikut.

Konstruksi atas realitas sosial (social construction of reality) adalah istilah yang diperkenalkan oleh Peter L. Berger dan Thomas Luckmann dalam buku yang diterbitkan tahun 1966, berjudul The Social Construction of Reality: A treatise in the Sociological of Knowledge. Menurut Berger dan Luckmann (1979), proses sosial digambarkan melalui tindakan dan interaksinya. Masing-masing individu menciptakan suatu realitas secara terus menerus dan dialami bersama-sama secara subjektif untuk kemudian membentuk realitas objektif yang disepakati bersama. Melalui berbagai kritik yang dikemukakan, teori Berger dan Luckmann (1979) telah dilakukan beberapa penyesuaian dengan melihat variabel media massa menjadi sangat substansi dalam proses eksternalisasi, objektivitas, dan proses internalisasi. Sehingga, sifat dan kelebihan media massa telah melengkapi dan memperbaiki kelemahan proses konstruksi sosial atas realitas yang sebelumnya berjalan lambat. Marc Ferro dalam Sutanto dan Harapan (eds.) (2003) menjelaskan bahwa sebagai media, film dapat digunakan sebagai sumber sejarah dan sebagai agen sejarah. Hal ini berarti bahwa kehadiran film dapat mengonstruksi realitas berbentuk pemahaman seseorang atas suatu kejadian di masa lalu/sejarah, meskipun realitas sendiri bersifat multifaset dan kompleks (Kolker, 2001).

Sebagai sebuah media, film memiliki lima faktor yang memengaruhi kebijakan redaksi dalam menentukan isi media, seperti dikemukakan oleh Shoemaker dan Reese (1996) dalam Mediating The Message: Theories of Influences on Mass Media Content, yaitu: faktor individual, rutinitas media, organisasi, ekstra media dan ideologi. Ide yang lain dikemukakan oleh Wicks (2005) dalam Communication Yearbook volume 19. Wick melihat ada empat variabel yang memengaruhi konstruksi frame dan konstruksi realitas sosial dalam media, antara lain: orientasi politik dan ekonomi media, praktik-praktik dan batasan dalam organisasi media, sistem kepercayaan jurnalistik yang berlaku dalam media dan teknik yang digunakan oleh media untuk menarik perhatian audiens.

Film adalah media komunikasi secara visual, alat penyampai gagasan dalam bentuk gambar. Gagasan tersebut dapat berupa informasi, hiburan, persuasi, maupun pendidikan. Film tidak lagi dimaknai hanya sebagai karya seni, tetapi lebih praktik sosial yaitu sebagai medium komunikasi massa yang beroperasi di dalam masyarakat yang di 
dalamnya terkandung nilai sosial. Kemampuan film dalam memberikan tampilan, baik dari segi audio maupun visual, mampu memberikan efek dramatis bagi para penonton yang mengapresiasi karya film. Kolker (2001) menjelaskan bahwa terdapat dua unsur pembentuk dalam film, yakni unsur naratif dan unsur sinematik yang saling berinteraksi satu sama lain. Unsur naratif bukan hanya bentuk yang digunakan oleh banyak film untuk mengisahkan cerita, namun sebenarnya adalah cerita itu sendiri (Kolker, 2001). Unsur naratif merupakan materi film yang diolah, seperti tokoh, masalah, konflik, dan lain sebagainya, sedangkan unsur sinematik adalah aspek teknis yang membentuk sebuah film seperti sinematografi, editing, framing, suara dan mise en scene (yang terlihat di depan kamera, dengan empat elemen pokok: latar, tata cahaya, kostum dan make-up). Semua hal tersebut mendukung keberadaan film sebagai teks atau wacana yang dihadirkan sebagai realitas bagi masyarakat. Film sebagai salah satu media komunikasi massa selalu merupakan potret dari kondisi masyarakat di mana film itu dibuat. Dalam film bertema sejarah, kondisi masyarakat saat film itu dibuat, sangat berpengaruh pada pembingkaian terkait apa saja yang ditampilkan dan tidak ditampilkan dalam film.

Model yang digunakan dalam penelitian ini dikemukakan oleh William A. Gamson dan Modigliani (dalam Eriyanto, 2001). Menurut mereka, frame adalah cara bercerita atau gugusan ide-ide yang terorganisir sedemikian rupa dan menghadirkan konstruksi makna peristiwa yang berkaitan dengan objek wacana. Kemasan (package) adalah serangkaian ide yang menunjukkan isu apa yang dibicarakan dan peristiwa mana yang relevan. Sebuah package memiliki struktur internal. Pada inti struktur tersebut, terdapat gagasan sentral (core frame) yang berisi elemen-elemen inti untuk memberikan pengertian yang relevan terhadap peristiwa, dan mengarahkan makna isu yang dibangun melalui condensing symbol. Selanjutnya, Gamson dan Modigliani menjelaskan bahwa condensing symbols terdiri dari Framing Devices, yang mengarahkan bagaimana cara melihat isu, dan reasoning device, yang memberikan alasan pembenar apa saja yang seharusnya dilakukan terhadap isu tersebut. Gamson mengemukakan bahwa alat framing (Framing Device) terdiri dari metaphors, exemplars, cacthphrase, pediction dan visual image. Sedangkan reasoning devices terdiri dari: roots, appeals to principle dan consequense (Eriyanto, 2001).

Sary (2013) menyatakan bahwa penggunaan analisis framing dalam film digunakan untuk melihat bagaimana aspek tertentu ditonjolkan atau ditekankan oleh media. Penonjolan dan penekanan aspek tertentu dari suatu realitas perlu untuk dicermati lebih jauh, karena penonjolan atau penekanan aspek tertentu dari suatu realitas akan membuat (hanya) bagian tertentu saja yang lebih bermakna, lebih mudah diingat, dan lebih mengena dalam pikiran khalayak.

\section{METODE PENELITIAN}

Jika dilihat dari empat dimensi paradigma, penelitian ini secara epistemologis menggunakan paradigma konstruktivis dan bersifat subjektif. Hal ini terjadi karena peneliti membuat konstruksi yang dilakukan oleh peneliti untuk menggambarkan kepemimpinan Soekarno melalui metafora, dialog, visualisasi, dan aspek lainnya dalam film. Secara ontologis, peneliti memiliki asumsi bahwa terjadi pembingkaian dalam membangun image kepemimpinan Soekarno terutama dalam setting masa pembuangannya di Ende. Peneliti bertujuan untuk merekonstruksi realitas sosial secara dialektis dengan film dan aspek-aspek yang diteliti. Secara metodologis, peneliti menggunakan metode analisis framing Gamson dan Modilgliani (dalam Eriyanto, 2001) untuk melihat konstruksi realitas yang dilakukan oleh Viva Westi selaku sutradara terhadap kepemimpinan Soekarno. Secara aksiologis, 
peneliti adalah instrumen utama dalam penelitian ini. Nilai-nilai yang menuntun penelitian ini adalah nilai-nilai yang ada dalam diri peneliti. Dalam penelitian ini, peneliti menggunakan paradigma konstruktivisme. Creswell (2010) menyatakan bahwa dalam paradigma konstruktivisme, peneliti bertujuan untuk memaknai atau menafsirkan makna-makna yang dimiliki orang lain tentang dunia ini, ketimbang mengawali penelitiannya dengan suatu teori.

Dalam penelitian ini, pendekatan yang digunakan adalah pendekatan kualitatif. Creswell (2010) menjelaskan bahwa peneliti kualitatif berperan untuk mengidentifikasi bias-bias, nilai-nilai, dan latar belakang pribadinya secara refleksif seperti gender, sejarah, kebudayaan, dan status sosial ekonominya, yang bisa saja turut membentuk interpretasi mereka selama penelitian. Dalam penelitian analisis wacana yang menggunakan paradigma konstruktivis, bisa menggunakan analisis framing sebagai metode penelitian. Penelitian ini menggunakan analisis framing dengan model yang dikemukakan oleh William A. Gamson dan Andre Modigliani (dalam Eriyanto, 2001) karena model Gamson dan Modigliani menitik beratkan pada aspek frame media yang terdiri dari gugusan ide-ide yang dikonstruksikan dalam suatu kemasan package. Konstruksi terkait Soekarno dan kepemimpinannya yang disampaikan melalui media film, merupakan rangkaian ide yang dikemas dalam bentuk penulisan skenario untuk kemudian ditampilkan secara audio visual; Kedua, Framing Devices dan reasoning devices yang digunakan oleh Gamson dan Modigliani berupa Metaphors, Catchphrases, Exemplar, Depiction, Visual images, Roots, Appeals to Principle dan Consequenses dirasa tepat untuk menganalisis media film yang mengandalkan kekuatan dialog, unsur audio visual dan penalaran kognitif sebagai medium penyampaian realitas dalam film.

Film ini dianalisis dengan melihat narasi percakapan, ilustrasi musik, dan adegan visual yang ditampilkan dalam film. Untuk itu, diperlukan analisis tekstual singkat untuk mendapatkan tema-tema yang digunakan oleh jurnalis atau sutradara film. Pola struktur naratif dalam film secara umum dibagi menjadi tiga tahapan yakni, permulaan, pertengahan serta penutupan. Pola ini mengacu pada struktur tiga babak (Pratista, 2008). Struktur tiga babak dalam film ini mengacu pada topik-topik utama yang membentuk narasi film secara keseluruhan. Peneliti mengobservasi keseluruhan film, lalu menemukan tiga topik utama dalam film, yaitu: Latar belakang Soekarno diasingkan ke Ende, Masa awal Soekarno di Ende dan menyesuaikan diri dengan Masyarakat Ende; dan Masa perenungan Soekarno hingga meninggalkan Ende.

Selain unsur naratif berupa alur cerita, data utama yang akan diteliti dalam penelitian ini adalah unsur sinematik berupa mise en scene, sinematografi, editing, dan suara. Namun penelitian akan dibatasi pada unsurunsur yang sesuai dengan tema penelitian. Pembatasan yang dilakukan peneliti dimaksudkan agar penelitian tidak melebar ke ranah film secara teknis. Kedua unsur utama itu akan dikodekan dalam sebuah bagan berdasarkan beberapa topik utama dalam film. Topik-topik tersebut kemudian akan dilihat per scene dan shots yang sesuai dengan tema kepemimpinan dalam penelitian ini. Selanjutnya, scene dan/atau shot tersebut dikategorikan ke dalam unsur-unsur yang ada dalam Framing Device (Perangkat Framing) dan Reasoning Device (Perangkat Penalaran), sesuai dengan metode framing yang digunakan, yaitu metode Gamson dan Modigliani. Dalam pendekatan metode model Gamson dan Modigliani ada dua aspek penting yang mendukung ide sentral atau gagasan sentral bisa diterjemahkan ke dalam sebuah realitas. Pertama, Framing Devices (perangkat framing) yang terdiri dari metaphors, exemplars, cacthphrase, depiction dan visual image. Perangkat ini berhubungan langsung pada penekanan bingkai dalam sebuah realitas dalam teks yang berkaitan dengan isu tertentu. Kedua adalah Perangkat penalaran (reasoning device) yang terdiri dari root, appeals to principle dan consequence. Perangkat penalaran ini berhubungan dengan 
kohesi dan koherensi dari realitas dalam teks suatu isu tertentu.

Sebagai data sekunder, peneliti melakukan penelusuran terhadap berbagai literatur yang ada, baik buku-buku, jurnal, tesis ataupun laporan-laporan penelitian terdahulu terkait penelitian ini. Kemudian peneliti akan mengambil bagian-bagian tertentu yang dianggap relevan dan mendukung data dalam penelitian ini. Penelusuran literatur ini juga berguna sebagai proses identifikasi awal peneliti terkait frames kepemimpinan Soekarno, khususnya di masa pembuangan Ende. Hasil identifikasi awal tersebut kemudian menuntun peneliti untuk mencari bukti-bukti dalam film dengan menggunakan teknik framing Gamson dan Modigliani.

Penelitian ini menggunakan data primer film "Ketika Bung di Ende" yang diproduksi oleh Kementerian Pendidikan dan Kebudayaan bersama PT. Cahaya Kristal Media Utama di tahun 2013 dan diunduh melalui situs www.youtube.com. Kesesuaian film yang diunduh tersebut telah mendapatkan validasi dari pihak sutradara dan penulis skenario sebagai versi yang otentik. Data sekunder yang digunakan adalah dengan melakukan penelusuran terhadap berbagai literatur yang ada. Data sekunder yang kedua, akan diambil dari wawancara peneliti terhadap Viva Westi selaku sutradara dan penulis skenario film ini. Wawancara dilakukan dengan menggunakan tipe pendekatan panduan wawancara (Interview Guide Approach) dengan karakteristik topik dan isu dispesifikasi dalam format pertanyaan-pertanyaan.

Ada beberapa keterbatasan dalam penelitian ini, antara lain: Penelitian ini hanya mengususkan tentang bagaimana konstruksi kepemimpinan Soekarno dalam satu bagian dari fase kehidupannya, semasa pembuangannya di Ende, Nusa Tenggara Timur, dikonstruksikan melalui film sebagai media sehingga tidak membahas tentang konstruksi kepemimpinan Soekarno sebagai tokoh bangsa secara keseluruhan semasa hidupnya. Fokus utama pada penelitian ini adalah pada analisis bagian-bagian dari film sebagai teks. Peneliti mengususkan pada teks dalam narasi atau dialog, visualisasi, dan suara. Visualisasi yang diteliti dikhususkan pada jenis pengambilan gambar (shots size) dan sudut pengambilan gambar sebagai unsur terpenting dalam jenis pengambilan gambar yang menentukan visualisasi dalam film. Adapun unsur lain seperti, jenis lensa, komposisi, fokus, pencahayaan dan kode sinematik tidak diteliti lebih jauh, untuk membatasi fokus penelitian. Data dalam level organisasi media, terbatas pada penelusuran literatur dan wawancara yang dilakukan terhadap Viva Westi sebagai sutradara sekaligus penulis skenario film, sehingga peneliti tidak mendapatkan gambaran yang utuh dan makro mengenai organisasi media dan pengaruh lain dalam organisasi media. Selain itu penelitian ini tidak melakukan analisis terhadap khalayak sehingga peneliti tidak dapat mengetahui bagaimana audiens memaknai kepemimpinan Soekarno dalam film tersebut sebagai suatu realitas objektif yang diinternalisasi dan memengaruhi konstruksi subjektif khalayak terhadap kepemimpinan Soekarno. Metode framing Gamson dan Modigliani ini biasanya digunakan untuk menganalisis teks berita melalui media cetak, dan dalam penelusuran yang dilakukan peneliti, hanya satu penelitian yang menggunakan metode ini untuk menganalisis film audio visual, sehingga dalam penelitian diperlukan beberapa adaptasi.

\section{HASIL PENELITIAN DAN PEMBAHASAN}

Sejak kemunculan pertamanya, film telah menjadi fenomena yang menarik. Hal ini dikarenakan seiring perkembangan teknologi dan penerapannya, film dapat dimasukkan dalam disiplin seni (sebagai hiburan maupun ekspresi pembuatnya), kajian komunikasi (sebagai media penyampaian pesan yang dipandang efektif), sejarah (terkait dengan kemampuannya menangkap jejak sejarah perkembangan peradaban sebuah bangsa, bahkan dunia) dan disiplin 
lainnya. Mengkaji dunia perfilman dari perspektif ilmu komunikasi adalah usaha untuk melihat film dalam potensinya untuk dijadikan media komunikasi yang efektif karena kemampuannya memadukan setidaknya dua teknologi media sekaligus, yaitu audio dan visual. Keberadaan film di Indonesia dimulai jauh sebelum kemerdekaan Indonesia dan mengalami pasang surut hingga saat ini. Pengaturan dan pelaksanaan segala hal terkait perfilman Indonesia dilakukan oleh Kementerian Pendidikan dan Kebudayaan. Namun sayangnya, sebelum film Ketika Bung di Ende, belum ada film Indonesia yang diproduksi oleh Kementerian Pendidikan dan Kebudayaan. Film Ketika Bung di Ende berdurasi 130 menit 58 detik, sejak awal hingga credit title berakhir. Terdiri dari 95 scene dan peneliti membaginya menjadi tiga tema/topik besar yang dibentuk oleh scene demi scene hingga membentuk cerita yang utuh.

Viva Westi adalah seorang sutradara dan penulis skenario film yang mengawali kariernya sebagai pemain film Surat untuk Bidadari pada tahun 1994. Lahir di Manokwari, 21 September 1972. Sebagai sutradara, dia sudah menyutradarai setidaknya tujuh judul film.

Di dalam film ini, peneliti menemukan tiga topik utama yang menyusun narasi cerita, yaitu: Latar belakang Soekarno diasingkan ke Ende (1 scene); Masa awal Soekarno di Ende dan menyesuaikan diri dengan Masyarakat Ende (77 scene); Masa perenungan Soekarno hingga meninggalkan Ende (17 scene). Setelah dilakukan analisis frame dengan metode Gamson dan Modigliani, ditemukan empat core frame dalam topik-topik tersebut, antara lain: Soekarno yang bersemangat yang gandrung pada persatuan; Soekarno yang berjiwa bebas dan anti imperialisme; Soekarno yang merangkul semua kalangan; dan Soekarno yang ideolog religius.

Empat core frames yang telah dijelaskan di atas merupakan dasar-dasar pemikiran yang membentuk sintesa ideologi dan falsafah bangsa Indonesia. Seperti pada kalimat terakhir yang diucapkan tokoh Soekarno dalam film tersebut, saat ditanya kesan yang didapat selama di Ende, "Saya menemukan falsafah fundamental penting untuk Indonesia". Core frame pertama yang menyatakan bahwa Soekarno adalah tokoh pergerakan yang gandrung pada persatuan sejalan dengan konsep nasionalis yang diusungnya. Sedangkan frame Soekarno sebagai seseorang yang berjiwa merdeka, anti imperialisme dan merangkul semua kalangan, sejalan dengan konsep sosialisme dengan proletarian Marxis. Sedangkan sosok Soekarno yang juga religius terutama saat memikirkan segala hal terkait bangsa Indonesia serta toleran terhadap umat beragama lain, sejalan dengan konsep agama Islam yang semasa di Ende dipelajarinya dengan lebih mendalam.

Keempat core frames di atas menunjukkan realitas kepemimpinan tokoh Soekarno yang ditampilkan dalam Film Ketika Bung di Ende sangat dipengaruhi oleh kondisinya saat itu dan juga kondisi masyarakat Ende dimana dia diasingkan. Proses berpikir dan merenung yang dialami Soekarno pada akhirnya mengerucut pada falsafah bangsa Indonesia di kemudian hari. Mengenai hal ini, Westi (2015) menyatakan bahwa selaku pelaku konstruksi, dia menyeleksi fakta-fakta apa yang ditampilkan untuk tujuan memberikan pemahaman sejarah secara utuh pada generasi muda melalui film. Terkait framing Soekarno sebagai ideolog religius, terdapat hal-hal yang ditampilkan antara lain, saat Soekarno berdoa, merenung, mengadakan pengajian dan menulis suratsurat terkait agama Islam kepada Ahmad Hassan. Dalam fim ini, isi dari surat-surat tersebut tidak dijelaskan secara rinci. Padahal jika diteliti lebih jauh, isi surat-surat tersebut banyak mengemukakan tentang pandangan kritis Soekarno terkait agama Islam. Daras (2013) membahas pandangan-pandangan kritis tersebut yang tampak dalam beberapa hal, antara lain: Gugatan Soekarno terhadap aristokrasi Islam dalam pengagungan terhadap "sayid" atau tokoh agama yang memiliki garis keturunan langsung Nabi Muhammad SAW, atau setidaknya memiliki keterikatan darah. Kritik Soekarno terhadap hadis-hadis lemah yang menurutnya telah 
membuat perilaku umat Islam bangsa Indonesia menyimpang dari hakikat agama Islam itu sendiri; Hadis palsu sebagai sumber kekolotan dan kekonservatifan kaum Islam Indonesia; Pertanyaan rasionalistis tentang kejadian Mi'raj dalam Isra Mi'raj; Kritik terhadap kebanggaan yang berlebihan terhadap Mesir dan Turki sebagai negara Islam yang dianggap berhasil; Kritik kaum agama Indonesia yang menyatakan bahwa demokrasi parlementer paling sesuai dengan asas-asas Islam; Pujian dan penghargaan Soekarno atas kerja keras misionaris di Flores saat itu. Soekarno juga menyalahkan sebagian umat Islam yang hanya mencela dan menggurui tapi tidak meniru hal positif dari misionaris tersebut. Menurutnya, hal ini yang membuat umat Islam selalu ada dalam masalah yang sama dan jauh dari kemajuan; kritik Soekarno tentang ajaran Islam yang hanya merujuk pada empat mahzab; dan Saran Soekarno agar Hassan lebih banyak mengajarkan ilmu pengetahuan Barat kepada santri-santrinya. Sehingga lebih bagus jika mempelajari Alquran dan Hadis dengan landasan ilmu pengetahuan yang kuat.

Berbagai pandangan kritis Soekarno terkait Islam tersebut tidak ditampilkan dalam film "Ketika Bung di Ende". Scene di mana Soekarno menulis surat kepada Ahmad Hassan hanya dinarasikan terkait kegelisahannya selama di Ende dan kedukaannya saat kehilangan Amsi, mertuanya. Pemikiran-pemikiran kritis yang menjadi inti dari ke 12 suratnya yang dikirimkan kepada Ahmad Hassan tidak tampak dalam film ini. Tampak bagaimana Viva Westi sebagai pelaku konstruksi dengan sengaja memilih realitas-realitas yang ditampilkan dan tidak ditampilkan dalam film yang dibuatnya.

Jika dikaitkan dengan teori yang dikemukakan oleh Shoemaker and Reese (1996), hal ini termasuk dalam kategori faktor individual dan ideologi yang dimiliki oleh pelaku konstruksi. Viva Westi beragama Islam dan tidak ingin konstruksi yang dibangunnya mengundang perdebatan bagi agama yang dianutnya. Viva Westi yang berjenis kelamin perempuan juga berpengaruh pada sisi romantisme dalam film yang dikonstruksi. Ideologi yang dianut Viva Westi, menuntunnya untuk melihat realitas Soekarno berdasarkan apa yang dia baca, dia lihat dan dia dengar, yaitu sebagai sosok pemimpin bangsa yang sangat mencintai Indonesia dan memiliki beberapa sisi yang berbeda namun tetap memiliki kapasitas sebagai pemimpin. Selanjutnya Westi juga menyatakan bahwa salah satu tujuan dia membuat film ini adalah keinginannya untuk membuat sesuatu bagi bangsa ini lewat film, sebagai pengalaman luar biasa dan bukan semata-mata keuntungan. Faktor individual dan ideologi ini oleh Wicks (2005) dikemukakan sebagai sistem kepercayaan individu yang diterima dalam media dan juga jenis teknik yang digunakan untuk menarik perhatian khalayak. Terkait teknik untuk menarik perhatian khalayak ini, Westi (2015) menyatakan bahwa teknik yang digunakan untuk menarik perhatian audiens antara lain pemunculan tokoh-tokoh baru dan alur cerita yang lamban yang mendominasi film ini. Faktor-faktor lain yang turut memengaruhi realitas yang ditampilkan yaitu organisasi dan ekstra media (Shoemaker and Reese, 1996) serta orientasi politik ekonomi media dan praktik dan batasan dalam organisasi media tidak banyak memengaruhi realitas yang dikonstruksi. Faktor-faktor organisasi, praktik dan batasan dalam organisasi media tidak memberikan banyak pengaruh dalam proses pembentukan realitas kepemimpinan Soekarno. Terlebih sumber pendanaan film ini berasal dari Kementerian Pendidikan dan Kebudayaan dan bersifat non profit sehingga faktor ekstra media, orientasi ekonomi politik dalam media tidak memberikan pengaruh besar dalam pembentukan realitas dalam film ini. Posisi media yang didukung penuh oleh pemerintah, menentukan kebebasan media tersebut dalam mengonstruksi realitas. Meskipun, tetap ada pemilihan realitas yang hendak ditampilkan dan tidak ditampilkan dalam film tersebut.

Jika ditarik pada teori konstruksi realitas, sebuah konstruksi realitas, selalu diawali dengan konstruksi subjektif yang ada pada benak individu tentang sosok Soekarno. 
Konstruksi subjektif tersebut terbentuk baik karena representasi Soekarno dalam film-film sebelumnya, maupun karena pengetahuan yang didapat dari media-media lain. Dalam kajian sastra, hal ini disebut intertekstualitas. Berdasarkan hasil wawancara peneliti dengan Westi (2015), ketertarikannya pada sejarah berawal dari kakeknya yang merupakan salah satu pejabat di era Soekarno. Sejak itu dia tertarik pada bidang sejarah dan biografi tokoh-tokoh besar. Menurut pernyataannya, film "Ketika Bung di Ende" ini dibuat melalui bermacam-macam buku, riset di Blitar, Surabaya, Ende, Bengkulu, Jakarta, dan Bandung; serta berdasarkan penyataan dari beberapa saksi hidup seperti putra putri Soekarno (Sukmawati, Guruh, Guntur, Toto), cucu anak angkat Inggit (Tito), anak angkat Sukarno dan Inggit (Popi) dan masyarakat Ende yang masih menyimpan dokumentasi beserta cerita turun temurun dari kerabat mereka yang pernah berinteraksi langsung dengan Soekarno. Semua teks yang diserap oleh Viva Westi melalui berbagai riset di atas, menjadikan film ini kaya intertekstualitas. Kehadiran tim riset yang juga membantu penulisan skenario film, semakin memperkaya intertekstualitas yang ditampilkan dalam film ini, mereka adalah Peter Kasenda, Roso Daras, Peter Rohi, dan Agnes Sri Purbasari. Semua hal yang disebutkan di atas telah diinternalisasi dan diobjektivasi oleh Viva Westi. Dalam proses objektivasi tersebut, Viva Westi melakukan seleksi tentang hal apa saja yang ditampilkan dalam film hasil eksternalisasinya.

Sebelum ada film Ketika Bung di Ende ini, setidaknya ada delapan film yang merepresentasikan Soekarno yang diproduksi oleh orang Indonesia, meskipun bukan sebagai pemeran utama. Di antara delapan film tersebut, dalam tujuh film Soekarno hanya sebagai tokoh pelengkap yang ditampilkan beberapa menit, sehingga konstruksi Soekarno menjadi sporadis dan tidak nyata. Mengenai hal ini, Viva Westi menyatakan bahwa film-film yang menampilkan sosok Soekarno yang pernah dibuat sebelumnya, tidak memengaruhi konstruksi yang dibangunnya dalam film
"Ketika Bung di Ende" ini. Mengenai film Soekarno yang disutradarai oleh Hanung Bramantyo, Viva Westi menyatakan bahwa dia tidak tahu menahu dan merasa lega saat tahu bahwa Hanung Bramantyo tidak memasukkan fase hidup Soekarno semasa di Ende dalam filmnya. Westi (2015) mengakui bahwa film adalah statement sutradaranya. Jadi setiap sutradara memiliki statement yang berbeda. Saat membuat film "Ketika Bung di Ende", Viva Westi bisa mengabaikan sisi komersil dan mengutamakan sisi kualitas secara lebih leluasa.

Hasil framing film "Ketika Bung di" Ende menampilkan sisi humanis Soekarno dan pandangan-pandangan yang menjadi sumber sintesa pemikirannya terkait falsafah dan dasar negara Indonesia sebagai sebuah bangsa, yang saat ini dikenal sebagai Pancasila. Hal ini sejalan dengan pernyataan Westi (2015): "Di Ende, aku ingin Soekarno dilihat sebagai manusia biasa. Bisa senang, sedih, bingung, putus asa, semua perasaanperasaan yang selama ini tidak kita ketahui dari seorang Soekarno-dia menemukan Pancasila dari kehidupan-kehidupan yang dia alami di Ende.... Jadi memang itu sangat kita sengaja bahwa scene by scene itu memang mencerminkan tentang Pancasila, tapi dibuat secara filmis.... Setiap perilakunya di film itu menunjukkan sisi Pancasila itu.... Jadi memang semua itu sudah kita sengaja dan kita siapkan agar Pancasila bisa masuk ke generasi muda".

Jika dikaitkan dengan paradigma kepemipinan baru Northouse (2013), Soekarno dapat dikategorikan sebagai pemimpin yang transformasional karena apa yang ditampilkan dalam film adalah Soekarno yang mampu menggerakkan pengikut untuk mencapai apa yang biasanya diharapkan dari mereka dengan emosi dan nilai tertentu. Jika merujuk pada teori yang dikemukakan Nimmo (1978), seperti telah dijelaskan sebelumnya, Soekarno termasuk dalam teori Constellation of Traits. Sehingga bisa disimpulkan bahwa kepemimpinan Soekarno dalam film "Ketika Bung di Ende", adalah kepemimpinan Constellation of Traits 
transformasional yang menganut falsafah Pancasila.

Sebagai salah satu media komunikasi, film "Ketika Bung di Ende" memperlihatkan bagaimana kepemimpinan tokoh bangsa dibingkai sedemikian rupa. Penggambaran tokoh bisa dilakukan melalui buku, tapi keberadaan film juga tidak kalah penting. Sehingga menarik untuk dikaji bagaimana film menggambarkan peran pemimpin di masa lalu, karena itulah tujuan penelitian ini adalah untuk membedah kepemimpinan tokoh bangsa melalui framing analysis.

\section{PENUTUP}

\section{Simpulan}

Berdasarkan perspektif Konstruksi Sosial Berger dan Luckmann (1979), media film bisa dikategorikan sebagai objektifikasi dalam konstruksi realitas. Realitas suatu peristiwa, dalam hal ini kepemimpinan tokoh Soekarno, internalisasikan oleh sutradara dan penulis skenario film sebagai media. Kemudian realitas itu diobjektivasi oleh sutradara film sehingga menjadi pengetahuan yang dimilikinya. Proses internalisasi dan objektivasi realitas tersebut melibatkan banyak hal, antara lain latar belakang, pengetahuan sebelumnya dan berbagai usaha lain melalui penelusuran literatur maupun riset khusus tentang tokoh Soekarno ini. Halhal tersebut, bersifat intertektualitas atau saling melengkapi antara teks satu dan teks lainnnya. Berbagai teks yang diinternalisasi dan diobjektivasi sutradara ini, kemudian membentuk pemahaman yang dimilikinya dan berpengaruh terhadap realitas yang disajikan melalui film "Ketika Bung di Ende".

Scene-scene dalam film "Ketika Bung di Ende" menunjukkan bagaimana realitas subjektif dari buku-buku, narasumber film, dan tim riset film diobjektivasi oleh Viva Westi, lalu dieksternalisasikan melalui semua unsur dalam film. Peneliti menemukan bahwa faktor individual (latar belakang keluarga, usia, pendidikan) Viva Westi memengaruhi ideologi yang dimilikinya dalam menafsirkan realitas kepemimpinan Soekarno. Sedangkan faktor organisasi dan ekstra media memiliki pengaruh kecil dalam konstruksi realitas dalam film "Ketika Bung di Ende". Hal ini berhubungan juga dengan sistem kepercayaan individual yang berlaku dalam media dan teknik yang digunakan untuk menarik khalayak. Dalam hal ini Viva Westi berusaha untuk menampilkan objektivitasnya sebagai sutradara dan penulis skenario dengan membuat film bertema sejarah yang jarang diangkat, dengan kualitas baik dan dapat membantu masyarakat untuk memahami sejarah secara lebih utuh tanpa terlalu terpengaruh akan orientasi politik dan ekonomi.

Dalam analisis film "Ketika Bung di Ende" dengan menggunakan perangkat analisis Gamson dan Modigliani, dapat ditemukan beberapa core frame, antara lain: Pemimpin bersemangat yang gandrung pada persatuan, berjiwa bebas dan anti imperialisme, merangkul semua kalangan, dan seorang ideolog religius. Semua core frame ini merujuk pada kepemimpinan yang sesuai dengan ideologi dan falsafah bangsa Indonesia. Pemikiran-pemikiran tersebut diterjemahkan sebagai Pancasila, yang menjadi dasar negara Indonesia. Semua core frame yang ditemukan dalam film, menunjukkan bagaimana Soekarno bisa mendekati dan menggerakkan masyarakat Ende bertransformasi menjadi lebih baik dan memiliki rasa nasionalisme yang tinggi. Kemampuan ini tidak dimiliki oleh banyak orang. Meskipun Soekarno terlahir sebagai rakyat biasa, tapi kualitas intelektual dan kepribadian membedakannya dari orang kebanyakan, hingga mengantarkannya menjadi pemimpin bangsa. Sehingga, kepemimpinan Soekarno dalam film "Ketika Bung di Ende" dikonstruksikan sebagai kepemimpinan berdasarkan constellation of traits yang transformasional, demokratis, dan menganut falsafah Pancasila.

\section{Saran}

Penelitian ini menggunakan paradigma konstruktivis yang memahami bahwa suatu realitas sosial sebagai realitas objektif 
dikonstruksi secara terus menerus oleh masyarakat dan media melalui realitas subjektif secara timbal balik (dialektis). Sehingga diperlukan penelitian lanjutan dengan melakukan penelitian langsung di masyarakat, misalnya degan reception analysis atau survei khalayak untuk mengetahui intepretasi mereka yang membentuk realitas subjektif mereka dan realitas objektif masyarakat.

\section{DAFTAR PUSTAKA}

Berger, P. L. and Luckmann, T. (1979). The Social Construction Of Reality: A Treatise In The Sociology Of Knowledge. London: Penguin Books.

Creswell, J. W. (2010). Research Design: Pendekatan Kualitatif, Kuantitatif dan Mixed (Terj. Achmad Fawaid). Yogyakarta: Pustaka Pelajar.

Daras, R. (2013). Total Bung Karno: Serpihan Sejarah yang Tercecer. Depok: Imania.

Dhakidae, D. (2013a). Dari Tempat Pembuangan Menjadi Rumah Pemulihan: Makna Soekarno bagi Ende, Ende bagi Soekarno. Prisma: Majalah Pemikiran Sosial Ekonomi Edisi Khusus, 32 (2 dan 3), Jakarta, p.113.

Dhakidae, D. (2013b). Soekarno: Memeriksa SisiSisi Hidup Putra Sang Fajar. Prisma: Majalah Pemikiran Sosial Ekonomi Edisi Khusus, 32 (2 dan 3), Jakarta, p.3.

Eriyanto. (2001). Analisis Wacana: Pengantar Analisis Teks Media. Yogyakarta: LKIS.

Eriyanto. (2007). Analisis Framing: Konstruksi, Ideologi dan Politik Media. Yogyakarta: LKIS.

Hamad, I. (2004). Konstruksi Realitas Politik Dalam Media Massa: Sebuah Studi Critical Discourse Analysis Terhadap Berita-Berita Politik. Jakarta: Granit.

Irawanto, B. (1999). Film, Ideologi, dan Militer: Hegemoni Militer Dalam Sinema Indonesia. Yogyakarta: Media Pressindo.

Kartono, K. (2006). Pemimpin dan Kepemimpinan. Jakarta: PT. Raja Grafindo Persada.

Kolker, R. P. (2001). Film, Form and Culture. Internat. Indianapolis: McGraw-Hill.

Luwarso, L., Southeast Asian Press Alliance (SEAPA) Indonesia and Friedrich Ebert
Stiftung (FES) Indonesia. (2002). Media: Pilar IV Demokrasi. Jakarta: SEAPA, Friedrich Ebert Stiftung, Dewan Pers.

Nimmo, D. D. (1978). Political Communication and Public Opinion in America. Santa Monica: Goodyear Pub. Co.

Northouse, P. G. (2013). Kepemimpinan: Teori dan Praktik. 6th ed. Jakarta: PT Indeks.

Pratista, H. (2008). Memahami Film. Yogyakarta: Homerian Pustaka.

Samuel, H. (1993). Perspektif Sosiologis Peter Berger. Jakarta: Pusat Antar Universitas Bidang Ilmu-Ilmu Sosial-Universitas Indonesia.

Sary, M. P. (2013). Analisis Framing Masalah Sosial Korupsi dalam Film Alangkah Lucunya Negeri Ini. In: Budianto, H., Leila Mona Ganiem and Tanti, D. S. (eds.), Identitas Indonesia Dalam Televisi, Film dan Musik, Prosiding Serial Call For Paper dan Konferensi Nasional Ilmu Komunikasi \#2 Komunikasi Indonesia Untuk Membangun Peradaban Bangsa, 2013, Bali: Pusat Studi Komunikasi dan Bisnis Program Pasca Sarjana Universitas Mercu Buana Jakarta, p.491-498.

Sen, K. (1994). Indonesian Cinema: Framing The New Order. London: Zed.

Shoemaker, P. and Reese, S. D. (1996). Mediating the Message, Theories of Infuences on Mass Media Content. New York: Longman Publishers.

Sutanto, I. and Harapan, A. A. (eds.). (2003). Prancis dan Kita, Strukturalisme Sejarah, Politik, Film dan Bahasa. Jakarta: Wedatama Widya Sastra.

Westi, V. (2015). Film "Ketika Bung di Ende". Wawancara oleh Septizar Triastika. Tanah Kusir, Jakarta. [Recording in possession of author].

Wicks, R. H. (2005). Message Framing and Constructing Meaning: An Emerging Paradigm in Mass Communication Research. In: Kalbfleisch, P. J. (ed.), Communication Yearbook 29, New York: Routledge. 